\title{
PENGEMBANGAN INSTRUMEN PENILAIAN BERBASIS HOTS (KETERAMPILAN BERPIKIR TINGKAT TINGGI) PADA TEMA EKOSISTEM SISWA KELAS V SD
}

\author{
I.G.W. Antara ${ }^{1}$, I.B.P. Arnyana ${ }^{2}$, I.G. margunayasa ${ }^{3}$ \\ ${ }^{123}$ Program Studi Pendidikan Dasar \\ Universitas Pendidikan Ganesha \\ Denpasar, Indonesia \\ e-mail: wisnu.antara@undiksha.ac.id ${ }^{1}$, putu.arnyana@undiksha.ac.id ${ }^{2}$, \\ igede.margunayasa@undiksha.ac.id ${ }^{3}$
}

\begin{abstract}
Abstrak
Penelitian ini bertujuan untuk mengetahui validitas dan reliabilitas dari pengembangan instrumen keterampilan berpikir tingkat tinggi (HOTS) IPA pada kelas V SD di Gugus VI Kecamatan Penebel. Jenis penelitian ini adalah penelitian dan pengembangan atau research and development dengan tahapan 4D, terdiri dari 4 tahap yaitu define, design, develop dan desimination. Namun pada tahap desimination tidak dilaksanakan karena situasi kesehatan masyarakat dengan adanya pandemic Covid 19. Pada tahapan ini menghasilkan instrumen keterampilan berpikir tingkat tinggi dalam bentuk pilihan ganda, yang kemudian divalidasi oleh tim ahli yang selanjutnya diujicobakan pada siswa. Berdasarkan hasil validasi ahli terhadap aspek materi, konstruksi, dan bahasa, instrumen dinyatakan valid dengan kategori sangat baik. Validitas isi tes melalui uji ahli menggunakan analisis CVR memperoleh hasil valid untuk semua soal. Hasil validitas butir dengan rumus point biserial memperoleh semua butir soal memiliki $r_{\text {hitung }}>r_{\text {tabel }}$ sehingga semua butir soal dinyatakan valid. Hasil uji reliabilitas tes memperoleh nilai sebesar 0,91 berada pada rentang $0,80<r_{1.1} \leq 1,00$ atau pada kategori derajat reliabilitas yang sangat tinggi. Jadi Instrumen penilaian keterampilan berpikir tingkat tinggi (HOTS) yang dikembangkan telah valid dan reliabel untuk dapat digunakan dalam mengukur keterampilan berpikir tingkat tinggi siswa.
\end{abstract}

Kata Kunci : Instrumen; Keterampilan Berpikir Tingkat Tinggi (HOTS); Pembelajaran IPA

\begin{abstract}
This study aims to determine the validity and reliability of the development of the instrument of higher order thinking skills (HOTS) of Science in class V SD in Cluster VI, Penebel District. This type of research is research and development or research and development with 4D stages, consisting of 4 stages, namely define, design, develop and desimination. However, the desimination stage was not carried out due to the public health situation with the Covid 19 pandemic. At this stage it produced an instrument of higher order thinking skills in the form of multiple choices, which was then validated by a team of experts which was then tested on students. Based on the results of expert validation on the material, construction, and language aspects, the instrument was declared valid in the very good category. The validity of the test content through expert testing using CVR analysis obtained valid results for all questions. The results of the validity of the items with the point biserial formula obtained that all items had $r_{\text {count }}>r_{\text {table }}$ so that all items were declared valid. The reliability test results obtained a value of 0.91 in the range $0.80<r_{1.1}<1.00$ or in the category of very high degrees of reliability. So the instrument for assessing higher order thinking skills (HOTS) that has been developed has been valid and reliable to be used in measuring students' higher order thinking skills.
\end{abstract}

Keywords : Instruments; High Level Thinking Skills (HOTS); Science learning 


\section{PENDAHULUAN}

Pendidikan di dunia ini sangat berperan dalam membangun kualitas sumber daya manusia. Pendidikan sangatlah penting untuk mendewasakan pemikiran seseorang guna untuk mencapai kesempurnaan dalam diri seseorang tersebut. Dalam Undangundang Nomor 20 Tahun 2003 tentang sistem pendidikan nasional menyatakan bahwa pendidikan adalah usaha sadar dan terencana untuk mewujudkan suasana belajar dan proses pembelajaran agar peserta didik secara aktif mengembangkan potensi dirinya untuk memiliki kekuatan spiritual-keagamaan, pengendalian diri, kepribadian, kecerdasan, akhlak mulia serta keterampilan yang diperlukan dirinya, masyarakat, bangsa dan Negara. Dalam kurikulum 2013 diberbagai jenjang pendidikan termuat berbagai muatan pelajaran, diantaranya PKN, IPA, IPS, Bahasa Indonesia, dan SBDP.

Dalam kurikulum 2013, proses pembelajaran IPA dapat dilaksanakan secara inkuiri ilmiah (scientific inquiry) untuk menumbuhkan keterampilan berpikir, dan dapat mengubah kondisi belajar peserta didik yang pasif menjadi aktif. Pembelajaran IPA diharapkan dapat mendorong peserta didik memenuhi kemampuan abad 21 dan salah satu kemampuan tersebut adalah keterampilan belajar dan berinovasi yang meliputi berpikir secara kritis.

Melihat pentingnya pembelajaran IPA diberikan kepada peserta didik, Menurut Donosepoetro (Trianto, 2012:13) "Pada hakikatnya IPA dibangun atas dasar produk ilmiah, proses ilmiah, dan sikap ilmiah. IPA dipandang pula sebagai proses, sebagai produk dan sebagai prosedur". Sementara itu Laksmi dkk (dalam Trianto, 2012:137) mengatakan bahwa "IPA hakikatnya merupakan suatu produk, proses, dan aplikasi”. Sejalan dengan hal tersebut menurut (Samatowa, 2010) menyatakan bahwa IPA pada hakikatnya memiliki dua dimensi penting didalamnya yaitu IPA sebagai produk dan IPA sebagai proses. IPA sebagai produk merupakan kumpulan hasil kegiatan empirik dan kegiatan analitik yang dilakukan para ilmuwan selama berabad- abad. IPA juga sering disebut sebagai ilmu universal, yang mendasari perkembangan teknologi modern saat ini, serta mempunyai peran penting dalam berbagai disiplin dan mamajukan daya pikir manusia. Keterampilan dalam berpikir memiliki peran yang sangat penting dalam keberhasilan IPA itu sendiri.

Menyadari pentingnya Pendidikan IPA tersebut pada jenjang sekolah dasar, aktivitas berpikir harus dibarengi dengan aktivitas belajar. Belajar dikatakan berhasil apabila dapat melalui berbagai macam aktivitas, baik aktivitas fisik maupun mental. Hal ini sejalan dengan pernyataan Mariana (2009) yang menyatakan bahwa peran dari SAINS atau IPA ialah memberikan pencerahan (enlighten) kepada manusia, maka dari itu SAINS atau IPA ini dikatakan sebagai power of investigation. Guru dalam kelas memiliki peran penting dalam mengatur dan memotivasi siswa untuk berpikir tingkat tinggi. Karena dengan menumbuhkan keterampilan siswa untuk berpikir, maka akan membantu siswa dalam bidang kognitifnya. Dapat dikatakan bahwa pembelajaran IPA itu sangat bermanfaat sekali bagi siswa tersebut, karena IPA mengajarkan mengenai diri sendiri dan lingkungan sekitar.

Namun pada kenyataannya, kualitas Pendidikan IPA di Indonesia belum bisa dikatakan mengalami peningkatan atau perubahan. Melihat hasil evaluasi yang bertujuan untuk mengetahui daya saing akademik peserta didik di Indonesia secara global yaitu hasil penilaian berskala internasional seperti Programme for International Student Assessment (PISA) dan Trends in International Mathematics and Science Study (TIMSS). Programme for International Student Assessment (PISA) sebagai program yang dilaksanakan oleh OECD pada tahun 2018 telah melakukan penelitian untuk melihat kemampuan literasi membaca, matematika, dan sains siswa berumur 15 tahun di 79 negara. Hasil penelitian tersebut menunjukkan bahwa kemampuan literasi sains anak Indonesia berada di peringkat 74 dengan skor 396 dari 79 negara, dimana hampir semua siswa Indonesia hanya menguasai pelajaran sampai level 3 saja dari 6 level, sementara 
siswa di negara maju maupun berkembang menguasai pelajaran sampai level 4, 5, bahkan 6 .

Melihat hasil penelitian yang sama dilakukan oleh Trends in International Mathematics and Science Study (TIMSS) yang menunjukkan kemampuan matematik peserta didik kelas IV dan kelas VIII SMP/MTs tahun 2015 Indonesia berada di urutan ke-45 dari 50 negara dengan skor 397 poin. Untuk IPA (Sains), Indonesia memperoleh skor yang sama sebesar 397 poin berada pada urutan 45 dari 48 negara. Sementara Singapura berada pada peringkat pertama dengan skor 567 (Kemendikbud, 2015). Survei ini dilakukan setiap empat tahun sekali. Suvei dilakukan pertama kali pada tahun 1999 dan terakhir kali pada tahun 2019. Untuk survei TIMSS 2019 ini, sampai dengan dilakukannya penelitian oleh penulis, bahwa hasilnya belum pernah dipublikasikan.

Ada beberapa hal penting yang mengakibatkan rendahnya kualitas pendidikan IPA diantaranya keterampilan berpikir siswa. Ketidakberhasilan mempelajari IPA dipengaruhi oleh objek IPA yang merupakan objek abstrak dan kesulitan guru dalam mengelola dan menyampaikan materi ajar sehingga menghasilkan ketidakbermaknaan belajar bagi para siswa. Selain itu, pembelajaran IPA di Indonesia seringkali menuntut siswa untuk banyak mempelajari konsep dan prinsip secara hapalan seperti menghapal perubahan yang terjadi di alam dan hubungannya dengan penggunaan sumber daya alam (SDA).

Menurut Lufri (2005) menyatakan bahwa pembelajaran akan menjadi hidup dan menarik bila pembelajaran tersebut mampu menggerakkan atau mengaktifkan daya pikir siswa. Kebosanan yang dialami peserta didik dalam proses pembelajaran IPA sebagian besar disebabkan oleh faktor didaktik, sehingga implikasinya terhadap keterampilan berpikir peserta didik menjadi rendah yang pada akhirnya bermuara ke hasil belajar peserta didik.

Berdasarkan proses berpikir Novak (Tawil \& Liliasari, (2013) menyatakan bahwa berpikir dapat dikelompokkan menjadi dua yaitu berpikir dasar dan berpikir kompleks. Proses berpikir dasar merupakan gambaran dari proses berpikir rasional, sedangkan berpikir kompleks disebut juga proses berpikir tingkat tinggi yang dikenal dengan High Orders Thinking Skills (HOTS).

Sejalan dengan hal tersebut Anderson dan Krathworl (2001) didalam Taksonomi Bloom keterampilan berpikir dibagi menjadi dua, yaitu keterampilan berpikir tingkat rendah (Lower Order Thinking Skill / LOTS) dan keterampilan berpikir tingkat tinggi (Higher Order Thinking Skill / HOTS). Keterampilan berpikir tingkat rendah melibatkan beberapa indikator diantaranya kemampuan mengingat (C1), memahami (C2), dan menerapkan (C3). Sedangkan dalam keterampilan berpikir tingkat tinggi melibatkan beberapa indikator diantaranya kemampuan analisis dan sintesis (C4), mengevaluasi (C5), dan mencipta atau kreativitas (C6). Dengan keterampilan berpikir tingkat tinggi yang diberikan kepada peserta didik ini akan dapat melatih kemampuan dalam menguasai konsep secara merata dan dicerna dengan baik, sehingga siswa tidak hanya menghafal materi yang diberikan namun namun siswa akan dapat menganalisis, mensintesis, mengevaluasi, dan mengkreasi suatu konsep dengan baik. Dengan konsep yang telah dipahami tersebut akan lebih lama melekat pada ingatan siswa. Sehingga sangat baik dan penting sekali bagi siswa untuk memiliki keterampilan HOTS ini

Dalam proses pembelajaran guru dapat melatih siswa untuk berpikir tingkat tinggi, kususnya dalam mata pelajaran IPA, pembelajaran IPA diberikan dengan dibarengi keterampilan HOTS akan menjadikan pembelajaran lebih bermakna bagi peserta didik. Dalam pembelajaran IPA guru dapat melatih keterampilan berpikir peserta didik dengan mengajak peserta didik melakukan sebuah eksperimen. Dengan melakukan eksperimen dalam pembelajaran IPA, guru memberikan siswa untuk menggali dan menemukan sendiri hipotesa yang ingin di cari, dengan demikian keterampilan berpikir siswa akan menjadi terlatih, sehingga nantinya akan tumbuh keterampilan berpikir tingkat tinggi. 
Namun pada kenyataannya, proses pembelajaran selama ini kurang mengembangkan keterampilan berpikir peserta didik termasuk keterampilan metakognitif. Proses pembelajaran lebih diarahkan pada kemampuan siswa dalam menghafal informasi dimana otak peserta didik dipaksa untuk mengingat dan menimbun informasi tanpa memahami informasi tersebut. Akibatnya, ketika peserta didik lulus, mereka hanya pintar dalam teori namun kurang dalam hal pengaplikasiannya karena peserta didik kurang diajarkan untuk menggunakan pemikirannya dalam memecahkan sebuah permasalahan. Hal ini sejalan dengan pendapat Hidayati, dkk (2017) yang menyatakan bahwa guru masih bingung bagaimana melatih siswa sekolah dasar untuk dapat berpikir tingkat tinggi.

Dengan permasalahan diatas, hal tersebut juga terjadi di Gugus Vi Kecamatan Penebel, Kabupaten Tabanan, dengan wawancara online yang dilakukan terhadap guru kelas $\mathrm{V}$ dan siswa kelas $\mathrm{V}$ didapatkan hasil, (1) Kemampuan guru dalam menyusun tes HOTS atau keterampilan berpikir tingkat tinggi masih terbatas. (2) Guru kurang memperhatikan tuntutan KI, KD dan indikator yang ada pada materi yang akan dibelajarkan dan dibuatkan tes hasil belajar, sehingga pencapaian kemampuan dari C1-C6 tidak lagi diperhatikan oleh guru. (3) Siswa belum dapat mengaplikasikan konsep pelajaran ke dalam kehidupan mereka, ini dikarenakan keterampilan berpikir siswa yang belum bisa mengaitkan materi-materi yang diberikan dengan kehidupan nyata yang dialaminya. (4) Guru belum memiliki dan belum pernah menyusun tes HOTS, Guru hanya mendapat soal IPA melalui internet. (5) Guru hanya melihat dan memeriksa jawaban akhir dari siswa dan tanpa ingin tahu bagaimana siswa menjawab soal tersebut, soal yang digunakan pada umumnya soal yang langsung menggunakan rumus tanpa proses analisa soal terlebih dahulu. Soal yang digunakan masih kurang sesuai dengan kriteria soal untuk mengukur keterampilan berpikir tingkat tinggi HOTS IPA. (6) guru menyadari pertanyaanpertanyaan yang diberikan kepada siswa masih bersifat faktual sehingga jarang mendorong siswa untuk berpikir lebih mendalam terhadap suatu permasalahan

Kemudian juga dilakukan observasi melalui metode luar jaringan yang diambil beberapa sampel siswa kelas $\mathrm{V}$ di setiap sekolah dasar di Gugus VI Kecamatan Penebel, Kabupaten Tabanan, dengan pendampingan oleh guru kelasnya masing-masing, kegiatan observasi dengan siswa yang terbatas ini diadakan karena adanya dampak pandemi COVID19 sehingga siswa dilarang untuk datang ke sekolah, serta kebetulan di gugus VI Kecamatan Penebel Kabupaten Tabanan ini guru diwajibkan tetap hadir di sekolah untuk memberikan tugas kepada siswa, siswa dipersilahkan untuk datang ke sekolah selama kurang lebih 10 menit secara begantian untuk melakukan kegiatan bersih-bersih di halaman sekolah, dengan hasil observasi adalah (1) masih banyak siswa yang mengatakan bosan dengan pembelajaran yang diberikan oleh guru, pemebalajaran yang diberikan oleh guru msaih bersifat monoton atau tidak bervariasi, (2) siswa hanya belajar duduk dan menjawab, tanpa ada kegiatan yang menarik atau melatih keterampilan berpikir siswa dimana guru hanya mengajarkan IPA dengan pembelajaran berpusat pada guru tanpa melatih bagaimana cara berpikir siswa tersebut. (3) siswa kurang bersemangat dalam menjawab soal yang diberikan oleh guru, karena tipe soal atau tes yang diberikan oleh guru, modelnya tidak berubah dari sebelum-sebelumnya. Serta tes yang dibuat belum memiliki kriteria keterampilan berpikir tingkat tinggi HOTS.

(4) Siswa belum bisa menentukan keterkaitan antara konsep IPA yang satu dengan konsep IPA yang lainnya. (5) Siswa tidak dapat menjelaskan kembali tentang konsep materi pembelajaran yang telah dipelajari, hal ini disebabkan karena minimnya pengetahuan dan kemampuan berpikir siswa dalam mencari pokok persoalan yang diberikan sehingga siswa mengalami kesulitan dalam penyampain materi yang sudah diajarkan. (6) Siswa masih dituntun dalam menyelesaikan suatu persoalan atau melakukan percobaan, jadi siswa kurang memiliki inisiatif diri ketika hendak belajar. 
Berdasarkan fakta permasalahan yang ditemui di gugus VI, Kecamatan Penebel, Kabupaten Tabanan, maka perlu dilakukan perbaikan dan pembaharuan dalam pembelajaran. Hal tersebut dapat dicapai dengan menerapkan sebuah pembelajaran yang kreatif dan inovatif, yang mampu menuntut siswa untuk terlibat langsung dalam pembelajaran sehingga muncul keterampilan berpikir tingkat tinggi dalam diri siswa. Serta salah satu alternatif juga dengan adanya perubahan dan pelatihan kepada guru mengenai pembaharuan mengenai cara menyusun soal atau instrumen penilaian yang sesuai dengan permasalahan tersebut, misalnya dengan mengembangkan tes keterampilan berpikir tingkat tinggi kususnya dalam pembelajaran IPA, sehingga dengan adanya pelatihan mengenai instrumen ini, guru akan memahami dan merancang sebuah instrumen yang dapat melatih pemikiran siswa menjadi berubah dan memiliki sebuah konsep dalam memecahkan suatu permasalahan. Menurut Ramos, Dolipas, dan Villamor. Guru masih belum mempersiapkan instrumen tes pada pembelajaran IPA dengan baik serta instrumen yang disusun belum memiliki keterampilan HOTS, sehingga masih banyak ditemukan ketidaksesuaian pengukuran yang dilakukan oleh guru, serta dalam mengukur keterampilan berpikir tingkat tinggi belum pernah diterapkan kepada peserta didik, yang nantinya mengakibatkan rendahnya keterampilan berpikir siswa dalam menjawab soal.

$$
\text { Permasalahan tersebut juga }
$$

didukung dengan penelitian yang telah dilakukan sebelumnya oleh Rusdianto (2020) yang menyatakan bahwa Jarangnya guru memberikan soal-soal yang menuntut kemampuan berpikir tingkat tinggi kepada peserta didik. Serta Khan dan Inamullah Rusdianto, (2020) yang menyatakan "guru lebih banyak memberikan soal-soal LOT kepada peserta didik dari pada soal-soal yang HOT'. Peserta didik tingkat sekolah dasar seharusnya mulai dilatih berpikir tingkat tinggi sesuai dengan usia mereka. Salah satu cara yang dapat dilakukan guru adalah memberikan soal-soal yang menuntut peserta didik berpikir yang tidak hanya sekedar mengingat, tetapi juga menganalisis, mengevaluasi bahkan mencipta. Selain itu Hernawan, (2018) dalam penelitiannya menunjukkan analisis kebutuhan (need assseement) instrumen asesmen berpikir kritis adalah $80 \%$. Salah satu penyebabnya adalah guru tidak membuat instrumen asesmen berpikir kritis, instrumen asesmen yang dibuat oleh guru masih terbatas pada tingkat pengetahuan (C1) dan pemahaman (C2), belum mengukur keterampilan berpikir kritis, dan instrumen asesmen keterampilan berpikir kritis siswa belum pernah dikembangkan oleh guru. Kemudian penelitian yang dilakukan oleh Kristianto, (2019) mengatakan bahwa sekolah sadar betul tentang pentingnya pengembangan kemampuan berpikir tingkat tinggi siswa untuk daya saing. Guru-guru disekolah juga sudah mengikuti workshop atau seminar mengenai pengembangan soal dan penilaian HOTS, namun pelaksanaanya belum sepenuhnya optimal. Mengingat soal ulangan harian, ataupun soal penilaian kenaikan kelas masih pada ranah C1 sampai C3 saja, terdapat C4 namun tidak banyak.

Di negara-negara maju saat ini, berkomitmen untuk meningkatkan cara berpikir tingkat tinggi (high order thinking), sedangkan pengetahuan konseptual cenderung dikurangi. $\mathrm{Hal}$ ini berbeda dengan di Indonesia yang masih menekankan pada konsep pengetahuan. Kelemahannya adalah banyak ditemui bahwa nilai ujian nasional siswa di Indonesia tinggi tetapi ketika dalam kehidupan nyata menghadapi suatu masalah, mereka tidak tahu bagaimana cara untuk mengatasi masalah tersebut. Berdasarkan fakta permasalahan tersebut, maka perlu dilakukan perbaikan dan pembaharuan dalam pembelajaran, memberikan pelatihan bagi guru dalam menyusun dan mengembangkan instrumen atau tes untuk melatih keterampilan berpikir tingkat tinggi, dan juga bagaimana cara mengembangkan instrumen yang valid dan reliabel. Berdasarkan hal tersebut dilakukan penelitian pengembangan yang bertujuan untuk mengetahui instrumen penilaian keterampilan berpikir tingkat tinggi pada 
pembelajaran IPA siswa kelas $\mathrm{V}$ yang valid dan reliabel.

\section{METODE}

Metode penelitian yang digunakan adalah metode penelitian dan pengembangan atau Research and Development (R\&D). Produk yang dikembangkan yaitu instrumen keterampilan berpikir tingkat tinggi pada pembelajaran IPA siswa kelas $\mathrm{V}$ SD Gugus VI Kecamatan Penebel pada Tema Ekosistem. Penelitian ini menggunakan model pengembangan yang mengikuti alur dari Thiagarajan (1974), yaitu menggunakan model 4D yang terdiri dari empat tahapan pengembangan yaitu tahap pendefinisian (define), tahap perancangan (design), tahap pengembangan (develop), dan tahap penyebaran (disseminate). Namun tahap penyebaran (disseminate) tidak dapat dilaksanakan karena kondisi dan situasi pandemic Covid-19.Subjek penelitian pengembangan instrumen adalah dosen ahli, guru (sebagai praktisi), dan siswa kelas V SD Gugus VI Kecamatan Penebel. Berikut ini tabel distribusi subjek penelitian.

Tabel 1. Distribusi Subjek Penelitian

\begin{tabular}{clc}
\hline No & \multicolumn{1}{c}{ Subjek } & Jumlah \\
\hline 1 & Dosen Ahli & 2 \\
2 & Guru Kelas V SD & 3 \\
3 & Siswa Kelas V SD & 50 \\
& Banyaknya subjek penelitian & 55 \\
\hline
\end{tabular}

Pengumpulan data yang digunakan dalam penelitian ini adalah data keterampilan berpikir tingkat tinggi. Instrumen yang digunakan untuk mengumpulkan data keterampilan berpikir tingkat tinggi adalah tes pilihan ganda (obyektif). Teknik pengumpulan data disajikan pada Tabel berikut::

Tabel 2. Teknik dan Instrumen Pengumpulan Data

\begin{tabular}{ccccc}
\hline No & Jenis Data & \multicolumn{1}{c}{ Teknik Pengumpulan Data } & Instrumen \\
\hline 1 & Validitas & 1. & $\begin{array}{l}\text { Pernyataan berupa saran dan masukan dari } \\
\text { dosen ahli }\end{array}$ & Tes Obyektif \\
& 2. $\begin{array}{l}\text { Uji coba di kelas terbatas } \\
\text { Uji Coba dengan menggunakan reponden } \\
\text { siswa sebanyak 50 siswa kelas V di Gugus VI } \\
\text { Kecamatan Penebel }\end{array}$ & Tes Obyektif \\
& & & \\
\hline
\end{tabular}

Uji validitas yang dicari adalah validitas isi dan validitas butir dari instrumen yang dibuat. Uji validitas isi menggunakan analisis Content Validity Ratio (CVR), formula ini digunakan karena dalam penelitian ini melibatkan lima pakar dengan alternatif penskoran (relevan dan tidak relevan). Menurut Lawshe (1975), menurut Lawshe (1975) dengan rumus sebagai berikut: $R \stackrel{n e^{-\frac{N}{E}}}{=} \quad \underline{N}^{2}$, Selanjutnya

2

peneliti melakukan analisis validitas isi dari aspek materi, aspek konstruksi, dan aspek bahasa. Pada aspek materi soal harus sesuai dengan indikator, setiap pertanyaan harus diberikan batasan jawaban yang diharapkan, materi yang ditanyakan harus sesuai dengan tujuan pengukuran, dan materi yang ditanyakan harus sesuai dengan jenjang dan jenis sekolah atau tingkat kelas. Pada aspek konstruksi soal menggunakan kata tanya/perintah yang menuntut jawaban terurai, ada petunjuk yang jelas tentang cara mengerjakan soal, setiap soal harus ada pedoman penskorannya, dan tabel, gambar, grafik, peta, atau yang sejenisnya disajikan dengan jelas, terbaca, dan berfungsi. Pada aspek bahasa rumusan kalimat soal harus komunikatif, menggunakan bahasa Indonesia yang baik dan benar, tidak menimbulkan penafsiran ganda, tidak menggunakan 
bahasa yang berlaku setempat/tabu, dan tidak mengandung kata/ungkapan yang menyinggung perasaan peserta didik.
Validitas dari aspek materi, konstruksi dan bahasa di analisis menggunakan rumus skala lima sebagai berikut :

Tabel 3. Skala Lima Instrumen

\begin{tabular}{c}
\hline Rentang Skor \\
\hline $\mathrm{M}_{\mathrm{i}}+1,5 \mathrm{SD}_{\mathrm{i}} \square \bar{X} \square \mathrm{M}_{\mathrm{i}}+3,0 \mathrm{SD}_{\mathrm{i}}$ \\
$\mathrm{M}_{\mathrm{i}}+0,5 \mathrm{SD}_{\mathrm{i}} \square \bar{X}<\mathrm{M}_{\mathrm{i}}+1,5 \mathrm{SD}_{\mathrm{i}}$ \\
$\mathrm{M}_{\mathrm{i}}-0,5 \mathrm{SD}_{\mathrm{i}} \square \bar{X}<\mathrm{M}_{\mathrm{i}}+0,5 \mathrm{SD}_{\mathrm{i}}$ \\
$\mathrm{M}_{\mathrm{i}}-1,5 \mathrm{SD}_{\mathrm{i}} \square \bar{X}<\mathrm{M}_{\mathrm{i}}-0,5 \mathrm{SD}_{\mathrm{i}}$ \\
$\mathrm{M}_{\mathrm{i}}-3,0 \mathrm{SD}_{\mathrm{i}} \square \bar{X}<\mathrm{M}_{\mathrm{i}}-1,5 \mathrm{SD}_{\mathrm{i}}$
\end{tabular}

Setelah memperoleh hasil validasi isi dari tes penilaian keterampilan proses sains maka draf II yang telah direvisi akan diujicobakan kepada 50 orang siswa dan diukurlah tingkat validitas butir soal dan reliabilitas dari tes tersebut.

Uji validitas butir menggunakan rumus korelasi yang digunakan untuk menguji data yang berbentuk dikotomi adalah teknik korelasi point biserial, dengan rumus sebagai berikut $r_{p b i}=$ $\underline{M_{P}-\frac{M_{t}}{S_{t}}} \sqrt{ }_{q}^{\bar{p}}$, suatu butir tes dinyatakan valid jika $r_{\text {hitung }}$ lebih besar daripada $r_{\text {tabel }}$ dengan taraf signifikansi atau taraf kekeliruan $5 \%\left(r_{\text {hitung }}>r_{\text {tabel }}\right.$ dengan t.s. $5 \%)$.

Sedangkan analisis reliabilitas menggunakan 50 siswa kelas $\mathrm{V}$ di gugus VI Kecamatan Penebel, dengan metode DARING (dalam Jaringan) melalui google form. Menurut Candiasa (2010) untuk mengetahui reliabilitas tes maka digunakan rumus $K R 21$. Adapun Rumus $K R 21$ yang dimaksud adalah: $r_{11}=\frac{k}{k-1}$ $\left\{1-\frac{M^{t}\left(k-M^{t}\right)}{k \cdot S_{t}^{2}}\right\}$ (Candiasa, 2010).

\section{HASIL DAN PEMBAHASAN}

Hasil dari penelitian pengembangan ini berupa instrumen penilaian berbentuk soal obyektif yang digunakan untuk menilai keterampilan berpikir tingkat tinggi (HOTS) pada pembelajaran IPA. Pengembangan instrumen penilaian keterampilan berpikir tingkat tinggi (HOTS) sains terdiri dari 3 tahapan, yaitu tahap pendefenisian (define), tahap perencanaan (design), tahap pengembangan (develop) dijelaskan sebagai berikut:

\author{
Sangat baik/Sangat tinggi \\ Baik/Tinggi \\ Cukup/Sedang \\ Tidak baik/Rendah \\ Sangat tidak baik/Sangat rendah
}

Klasifikasi / Predikat

(Sumber: dimodifikasi dari Koyan, 2012)

1. Tahap Pendefinisian (Define).

Tahap pendefinisian bertujuan untuk menetapkan dan mendefinisikan syaratsyarat pembelajaran. Kegiatan yang dilakukan dalam tahap pendefinisian, meliputi analisis awal-akhir, analisis siswa, analisis konsep, analisis tugas dan spesifikasi tujuan pembelajaran. Kegiatan analisis awal-akhir dilakukan untuk menetapkan masalah dasar yang diperlukan dalam pengembangan instrumen tes kemampuan berpikir tingkat tinggi. Pada tahap ini dilakukan telaah terhadap kompetensi dasar (KD) kelas $\mathrm{V}$ semester I serta materi yang sudah diberikan oleh sekolah khususnya dalam materi IPA pada tema ekosistem sehingga memudahkan langkah awal dalam mengembangkan intrumen pengukuran atau tes-tes kemampuan berpikir tingkat tinggi yang sesuai untuk dikembangkan.

Selanjutnya analisis konsep adalah mengidentifikasi, merinci dan menyusun secara sistematis konsep-konsep topik disesuaikan dengan materi IPA yang diujikan di kelas V semester I. Salah satu kegiatan dalam analisis konsep ini adalah mencari dan membaca referensi kerangka kerja pengukuran kemampuan berpikir tingkat tinggi, kemudian tak lupa untuk membaca buku-buku IPA SD kelas $\mathrm{V}$ semester I yang mendukung penyusunan instrumen keterampilan berpikir tingkat tinggi.

Selanjutnya analisis tugas adalah mengidentifikasi keterampilan dasar yang dimiliki siswa tentang topik yang diujikan. Analisis ini digunakan untuk memunculkan kemampuan berpikir tingkat tinggi siswa kelas V SD. Pemilihan soal ini disesuaikan dengan materi IPA dan bersifat konstekstual. 
Setelah melakukan analisis tugas siswa, dilanjutkan dengan tahap ini bertujuan untuk mengkonversi tujuan dari analisis tugas dan analisis konsep menjadi tujuan khusus yaitu untuk mengembangkan instrumen pengukuran kemampuan berpikir tingkat tinggi.

\section{Tahap Perancangan (Design)}

Tujuan dari tahap ini adalah untuk merancang bentuk dasar dari instrumen pengukuran keterampilan berpikir tingkat tinggi. Pada tahap perancangan ini terdiri dari beberapa langkah pokok yaitu sebagai berikut:

\section{a. Penyusunan Tes}

Dasar dari penyusunan soal adalah analisis konsep dan analisis tugas yang dijabarkan dalam spesifikasi instrumen pengukuran kemampuan berpikir tingkat tinggi, selanjutnya disusun kisi-kisi dan acuan penskorannya menurut dimensi kemampuan berpikir tingkat tinggi.

\section{b. Pemilihan Format}

Pemilihan format dalam pengembangan instrumen pengukuran kemampuan berpikir tingkat tinggi belajar mencakup pemilihan format untuk merancang isi dan topik yang diujikan, yang dimana dalam penelitian ini instrumen tes bertipe analisis, memecahkan suatu masalah dan bersifat konstekstual.

\section{c. Perancangan Awal}

Rancangan awal yang dimaksud ialah rancangan seluruh instrumen yang dikerjakan sebelum soal diujicobakan. Pada tahap ini menghasilkan versi awal Draft 1 yang selanjutnya di revisi terlebih dahulu oleh pembimbing. Pada tahap ini menghasilkan versi awal Draft I yang selanjutnya disempurnakan melalui proses pada tahapan pengembangan.

\section{Tahap Pengembangan (Develop)}

Tujuan dari tahap ini adalah menghasilkan Draft I berupa instrumen yang telah direvisi berdasarkan masukan para ahli dan data yang diperoleh dari uji coba, adapun para ahli yang terlibat dalam proses validitas isi instrumen tes untuk mengukur keterampilan bepikir tingkat tinggi antara lain dua orang dosen ahli dari jurusan Pendidikan dasar yaitu Prof. Dr.
Ida Bagus Putu Aryana, dan Dr. I Gede Margunayasa,S.Pd.,M.Pd. selain itu juga, divalidasi oleh 3 orang praktisi yakni guru yang berprofesi sebagai guru sekolah dasar yaitu, Ni Nyoman Metamin, S.Pd mengajar di SD N 4 Babahan, Ni Nyoman Siwi, S.Pd mengajar di SD N 4 Senganan, dan $\mathrm{Ni}$ Nyoman Ayu Sriwijati, S.Pd mengajar di SD N 5 Senganan sehingga pada tahapan ini merupakan tahapan lanjutan untuk menyempurnakan Draft I sebelum akhirnya menjadi versi final. Kegiatan pada tahap ini adalah penilaian para ahli dan pengujian pengembangan.

Adapun saran yang diberikan para ahli, dimulai dari saran ahli atau judges I-V adalah sebagai berikut. Judges 1 memberikan penilaian relevan untuk semua butir soal pada instrumen keterampilan berpikir tingkat tinggi. Keseluruhan butir soal pada instrumen tersebut dianggap telah sesuai dengan indikator yang dicantumkan. Namun terdapat beberapa saran umum yang diberikan oleh judges I untuk dapat lebih dicermati lagi. Judges II memberikan penilaian relevan untuk semua butir soal pada instrumen keterampilan berpikir tingkat tinggi. Keseluruhan butir soal pada instrumen tersebut dianggap telah sesuai dengan indikator yang dicantumkan. Namun terdapat beberapa saran dari setiap butir soal yang diberikan oleh judges // untuk dapat lebih dicermati lagi, adapun kesalahan atau perbaikan yang diberikan oleh judges II. Judges III, merupakan rekan guru kelas $\mathrm{V}$ yang bertugas di SD $\mathrm{N} 4$ Babahan. memberikan penilaian relevan untuk 50 butir soal pada instrumen keterampilan berpikir tingkat tinggi. Menurutnya, instrumen ini telah sesuai dengan dimensi dan indikator yang dicantumkan. Terdapat beberapa hal yang perlu dicermati untuk menyempurnakan beberapa butir soal dalam instrumen yang disampaikan berupa saran secara umum. Judges IV, merupakan rekan guru kelas $\mathrm{V}$ yang bertugas di SD N 4 Senganan. Menurut jugdes IV 50 butir soal pada instrumen telah memenuhi dan sesuai dengan dimensi serta indikator yang digunakan, namun ada 3 butir soal yang menurut judge IV ini kata-kata butir soalnya kurang dimodifikasi sedikit dan lebih dirujuk agar 
siswa tidak bingung, yakni soal no 12, 13, 14 tabel 4.5 Saran umum judges IV. Judges $\mathrm{V}$, merupakan rekan guru kelas $\mathrm{V}$ yang mengajar di SDN 5 Senganan. Menurutnya, setiap butir soal yang terdapat pada instrumen keterampilan berpikir tingkat tinggi memiliki tingkat kesukaran yang berbeda-beda. Beberapa butir soal yang dibuat dianggap telah sesuai jika digunakan untuk mengukur keterampilan berpikir tingkat tinggi siswa kelas $\mathrm{V}$, namun ada juga beberapa butir soal yang masih terlalu sederhana jika dikerjakan oleh siswa kelas V SD. Judges $\mathrm{V}$ memberikan penilaian relevan untuk 50 butir soal yang dianggapnya telah sesuai dan relevan. Namun ada beberapa hal yang menjadi kendala, yakni siswa masih belum mahir dalam menjawab menggunakan google form, karena pengaruh sinyal di lingkungan siswa tersebut, namun berkat kerjasama dan bimbingan bersama siswa bisa menjawab dengan lancar.

Selanjutnya berdasarkan hasil analisis uji validitas, validitas isi yang dilakukan pada instrumen tes keterampilan berpikir tingkat tinggi dengan menggunakan teknik analisis CVR, setiap butir soal memiliki nilai CVR $\geq 1,00$ yang artinya semua butir soal pada instrumen dinyatakan valid. Ahmad dkk (2018) menyatakan bahwa tes dinyatakan valid ini membuktikan bahwa validator telah menyatakan bahwa tes layak untuk digunakan. Berdasarkan hasil rerata intrumen tes keterampilan berpikir tingkat tinggi memiliki kriteria sangat baik pada aspek materi, konstruksi dan bahasa dengan rerata masing-masing aspek materi memperoleh rata-rata 23,8 berada pada kategori sangat baik, aspek konstruksi memperoleh rata-rata 24,2 berada pada kategori sangat baik, dan pada aspek bahasa memperoleh rata-rata 23,4 berada pada kategori sangat baik. $\mathrm{Hal}$ ini sesuai dengan pendapat Masitoh (2020) yang menyatakan bahwa setelah dinyatakan valid dengan mendapat catatan perbaikan, maka instrumen siap digunakan dalam uji coba.

Setelah dilakukan uji coba dengan 50 orang siswa di gugus VI kecamatan Penebel, didapatkan hasil semua semua butir soal memiliki $r_{\text {hitung }} \square \quad$ atau semua butir soal dinyatakan valid sehingga semua soal digunakan. Hal ini sesuai dengan pendapat Sugiyono (2015) yang menyatakan bahwa data yang valid berarti data tersebut dapat digunakan untuk mengukur apa yang seharusnya diukur.

Selanjutnya setelah melakukan uji validitas butir, dilanjutkan dengan uji reliabilitas. Menurut Mulyasa (2009) menyatakan bahwa reliabilitas merupakan salah satu ciri dari suatu instrumen asesmen dimana soal yang digunakan adalah sebagai alat ukur yang dapat mengukur skor peserta tes yang benarbenar dapat menggambarkan kemampuan mereka. Hal tersebut sejalan dengan pendapat Winarno (2011:107) yang menyatakan bahwa reliabilitas instrumen diartikan sebagai keajegan (consistency), karena keajegan dari instrumen itu sangat berpengaruh terhadap hasil yang diperoleh dari jawaban siswa. Berdasarkan hasil analisis reliabilitas menggunakan rumus KR 21 diperoleh nilai $r_{11}$ sebesar 0,91 berada pada rentang 0,80 $<r_{1.1} \leq 1,00$ atau pada kategori derajat reliabilitas yang sangat tinggi. Menurut Masitoh (2020) menyatakan bahwa apabila hasil dari uji reliabilitas berada pada kategori tinggi dan sangat tinggi maka instrumen tersebut bisa dikatakan ajeg, dengan demikian dapat dikatakan bahwa instrumen yang telah disusun sudah reliabel.

Dengan penggunaan instrumen keterampilan berpikir tingkat tinggi ini, siswa menjadi sangat terampil dalam bertanya dan mengemukakan pendapatnya, menemukan sebuah informasi yang relevan, berusaha mencari berbagai alternative untuk mendapatkan solusi, serta dapat menentukan cara yang efektif dalam menyelesaikan masalah pada soal keterampilan berpikir tingkat tinggi.

Hal ini sejalan dengan penelitian yang telah dilakukan oleh Rusdianto (2020) yang menyatakan bahwa jarangnya guru memberikan soal-soal yang menuntut kemampuan berpikir tingkat tinggi kepada peserta didik, maka siswa tidak akan memiliki kemampuan untuk berpikir dan memecahkan suatu permasalahan 
Kemudian penelitian yang dilakukan oleh Kristianto (2019) mengatakan bahwa sekolah sadar betul tentang pentingnya pengembangan kemampuan berpikir tingkat tinggi siswa untuk daya saing. Guru-guru disekolah juga sudah mengikuti workshop atau seminar mengenai pengembangan soal dan penilaian HOTS, namun pelaksanaanya belum sepenuhnya optimal. Mengingat soal ulangan harian, ataupun soal penilaian kenaikan kelas masih pada ranah C1 sampai C3 saja, terdapat $\mathrm{C} 4$ namun tidak banyak.

Serta hasil dari penelitian Pratiwi (2015) Proses pengembangan instrumen penilaian HOTS dan sikap disiplin masingmasing terdiri dari 12 indikator dengan skor maksimal 4.00 menghasilkan: Instrumen penilaian adalah valid menurut 4 (empat) validator, yaitu diperoleh ratarata nilai validitas 3,57. Instrumen penilaian dikatakan efektif/berhasil, karena mencapai kesuksesan instrumen penilaian dengan skor HOTS $73,3 \%$ dan sikap disiplin $90 \%$ dari skor total.

Berdasarkan hasil analisis dan temuan dalam penelitian lain yang sesuai dengan penelitian ini, sehingga dapat disimpulkan bahwa hasil analisis yang telah diperoleh yaitu analisis uji validitas isi dengan CVR, validitas butir dengan Point Bisserial dan analisis uji reliabilitas dengan KR21, maka instrumen keterampilan berpikir tingkat tinggi IPA merupakan instrumen yang valid isi dan reliabel.

Pada penelitian ini memiliki perbedaan dengan penelitian yang sudah dilaksanakan sebelumnya, diantaranya

adalah penelitian ini menggunakan sub materi yang berbeda, yakni menggunakan sub materi tema Ekosistem pada kelas $\mathrm{V}$ SD semester 1, penelitian ini membahas mengenai cara mengembangkan instrumen tes keterampilan berpikir tingkat tinggi (HOTS) yang sesuai dengan standar yang diterapkan di sekolah dasar, penelitian ini juga sangat bermanfaat bagi Guru-guru sekolah dasar untuk lebih mengetahui cara mengembangkan instrumen tes keterampilan berpikir tingkat tinggi (HOTS) sesuai dengan standar yang sudah ada, serta penelitian ini juga memberikan manfaat bagi siswa, karena para siswa akan dilatih untuk berpikir secara kreatif dan kritis dalam menjawab soal atau memcahkan suatu permasalahan yang diberikan oleh guru dalam proses pembelajaran, begitu juga dalam kehidupan sehari-hari, para siswa akan mempunyai ide-ide kreatif yang dapat berguna bagi dirinya sendiri.

Hasil dari penelitian ini juga sangat bermanfaat bagi Pendidikan pada umumnya. Karena para pendidik yang mengalami kesulitan dalam mengembangkan suatu instrumen tes keterampilan berpikir tingkat tinggi, penelitian ini dapat dijadikan sebagai acuan untuk mengembangkan instrumen yang sejenis, serta dapat mengembangkan lagi ke dalam model instrumen yang lainnya.

\section{PENUTUP}

Berdasarkan analisis data yang telah dilaksanakan dengan pengujian validitas isi menggunakan teknik Lawshe yaitu Content Validity Ratio (CVR) diperoleh 50 butir soal valid dengan nilai CVR $=1,00$. Hasil rerata pada aspek materi, aspek konstruksi dan aspek bahasa/budaya memiliki kriteria sangat baik. Dengan rerata masing-masing aspek materi memperoleh rata-rata 23,8 berada pada kategori sangat baik, aspek konstruksi memperoleh rata-rata 24,2 berada pada kategori sangat baik, dan pada aspek bahasa memperoleh rata-rata 23,4 berada pada kategori sangat baik.

Selanjutnya beradasarkan uji validitas butir dengan menggunakan rumus point biserial diperoleh semua butir soal memiliki $r_{\text {hitung }} \square$ atau semua

$$
r_{\text {tabel }}
$$

butir soal dinyatakan valid. Sedangkan nilai yang diperoleh pada pengujian reliabilitas menggunakan KR21 instrumen tes keterampilan berpikir tingkat tinggi IPA memperoleh nilai 0,91 berada pada rentang $0,80<r_{1.1} \leq 1,00$ atau pada kategori derajat reliabilitas yang sangat tinggi. Maka instrumen tes keterampilan berpikir tingkat tinggi tersebut bisa dikatakan ajeg/reliabel untuk digunakan mengukur hasil belajar siswa. Dengan demikian dapat disimpulkan bahwa instrumen keterampilan berpikir tingkat tinggi IPA dinyatakan valid dan reliabel.

\section{DAFTAR RUJUKAN}


Ahmad, S, Ary. K.K, Masniladevi. 2018. Instrumen HOTS Matematika Bagi Mahasiswa PGSD. Jurnal PAJAR (Pendidikan dan Pengajaran) Program Studi Pendidikan Guru Sekolah Dasar FKIP Universitas Riau. Volume 2 Nomor 6 November 2018 | ISSN Cetak : 2580 - 8435 | ISSN Online : 2614 - 1337

Anderson, L.W., dan Krathwohl, D.R. 2001. A Taxonomy for learning, Teaching, and Assesing; A revision of Bloom's Taxonomy of Education Objectives. New York: Addison Wesley Lonman Inc.

Candiasa, I Made. 2010. Pengujian Instrumen Penelitian Disertai Aplikasi ITEMAN dan BIGSTEPS. Singaraja: Undiksha Press.

Hidayati, Arini Ulfah. 2017. Melatih Keterampilan Berpikir Tingkat Tinggi dalam Pembelajaran Matematika pada siswa Sekolah Dasar. Yogyakarta. Jurnal Pendidikan dan Pembelajaran Dasar, Volume 4 Nomor 2 Oktober 2017, p-ISSN 2355-1925, e-ISSN 2580-8915

Koyan. 2012. Statistik Pendidikan teknik analisis data kuantitaif. Singaraja: UNDIKSHA.

Lawshe, C. H. (1975). A quantitative approach to content validity. Jurnal Personnel psychology, Vol 28, No. 4.

Lufri. 2005. "Pengaruh Pembelajaran Berbasis Problem Solving yang Diintervensi Dengan Peta Konsep terhadap Hasil Belajar mahasiswa". Jurnal Pembelajaran. Volume 28, Nomor 1 (hlm 153-166).

Kistiono. 2019. Pengembangan Tes Kemampuan Berpikir Tingkat Tinggi Fisika SMA. Universitas Sriwijaya. Jurnal Inovasi dan Pembelajaran Fisika. (Journal of Innovation and Physics Teaching). Volume 06, No. 1, Mei 2019, hal. 70-81. p-ISSN 2355-7109 e-ISSN 2657-0971; ejournal.unsri.ac.id/index.php/JIPF

Mariana, I Made dan Wandy Praginda.2009. Hakikat IPA dan Pendidikan IPA. Bandung. Pusat Pengembangan dan Pemberdayaan
Pendidik dan Tenaga Kependidikan IImu Pengetahuan Alam (PPPPTK IPA)

Masitoh, Lisda Fitriana, dan Weni Gurita Aedi. 2020. Pengembangan instrumen asesmen Higher order thinking skills (HOTS) matematika Di SMP kelas VII. Jurnal Cendekia: Jurnal Pendidikan Matematika. Volume 04, No. 02, November 2020, pp. 886-897. E-ISSN : 2579-9258. PISSN : 2614-3038

Mulyasa, E. 2009. Analisis, Validitas, Reliabilitas, dan Interpretasi Hasil Tes Implementasi Kurikulum 2004. Bandung: Remaja Rosdakarya.

OECD. 2018. PISA 2018 Assessment and Analytical Framework Mathematics, Reading, Science, Problem Solving and Financial Literacy. OECD Publishing.

Pratiwi, Umi dan Eka Farida Fasha. 2015. Pengembangan Instrumen Penilaian HOTS Berbasis Kurikulum 2013 Terhadap Sikap Disiplin. Purworejo. Jurnal enelitian dan Pembelajaran IPA. JPPI, Vol. 1, No. 1, November 2015, Hal. 123-142. e-ISSN 24772038

Rusdianto, Andy. 2020. Pengembangan instrumen penilaian berbasis Higher Order Thinking Skill (HOTS) Pelajaran matematika kelas IV Sekolah Dasar. JP3D (Jurnal Pembelajaran dan Pengajaran Pendidikan Dasar). Vol. 3 No. 1, 2020. ISSN (print): 2654-2870; ISSN (online) 2686-5483 Available online at

https://ejournal.unib.ac.id/index.php/ dikdas/index; doi: http://dx.doi.org/10.33369/

Sugiyono. (2015). Metode Penelitian \& Pengembangan.

Bandung: ALFABETA.

Tawil, M. \& Liliasari. (2013). Berpikir kompleks dan ilmplementasinya dalam pembelajaran IPA. Makasar: Badan Penerbit UNM.

Thiagarajan.(1974) Instructional Development for Training Teacher of Exceptional Children A sourcebook. 
Vol. 5 No 2, Agustus 2021

ISSN: 2613-9553

Indiana University, Bloomington:

Indiana.

Trianto. 2012. Model Pembelajaran Terpadu. (Jakarta: PT Bumi Aksara).

Winarno, M.E. 2011. Metodologi Penelitian dalam Pendidikan Jasmani. Malang: Media Cakrawala Utama Press 